\title{
The Development and Change of Kyakhta Trade in the 18th and 19th Centuries
}

\author{
Zhimin Huang ${ }^{1,2}$ \\ ${ }^{1}$ Center for Mongolian Studies, Inner Mongolia University, Hohhot, China \\ ${ }^{2}$ School of Tourism, Inner Mongolia University of Finance and Economics, Hohhot, China \\ Email:zmhminmin@163.com
}

How to cite this paper: Huang, Z. M. (2019). The Development and Change of Kyakhta Trade in the 18th and 19th Centuries. Advances in Historical Studies, 8, 131137.

https://doi.org/10.4236/ahs.2019.83010

Received: March 31, 2019

Accepted: June 8, 2019

Published: June 11, 2019

Copyright $\odot 2019$ by author(s) and Scientific Research Publishing Inc. This work is licensed under the Creative Commons Attribution International License (CC BY 4.0).

http://creativecommons.org/licenses/by/4.0/

\begin{abstract}
The Treaty of Kyakhta signed in 1728 has not only political significance, but also commercial significance for the Qing Dynasty and Russia. The signing of the Treaty of Kyakhta has legalized private transactions between the Qing Dynasty and Russian businessmen prior to that date through official recognition. At the same time, it also means the establishment of Kyakhta's intermediary status in trade between the Qing Dynasty and Russia and even Europe as a whole. The development of Kyakhta trade is analyzed in this article through the changes of Kyakhta trade management methods by the Qing Dynasty government in the 18th and 19th centuries, as well as the characteristics of the merchants and commodities of the Kyakhta border trade during this period.
\end{abstract}

\section{Keywords}

18th to 19th Century, Kyakhta, Trade

\section{Introduction}

It is widely believed that the southeastern coastal trading ports opened in the 19th century has incorporated the vast Chinese market under the Qing Dynasty into the world trade market. However, in fact, in the early and middle period of the Qing Dynasty, the Qing Dynasty and Russia had already launched land-based international trade activities on the Mongolian Plateau through the Treaty of Nybchu and the Treaty of Kyakhta. In 1728, the Ding Dynasty signed The Treaty of Kyakhta with Russia, and the two countries officially carried out border trade relations in Kyakhta. Kyakhta has become the main place for the international trade between the Qing Dynasty and Russia and gradually established the mo- 
nopoly intermediary status in the trade between the Qing Dynasty and Europe. This situation has lasted for more than one hundred years until the 1940s, when Kyakhta gradually lost its monopoly position with the successive opening of trading ports along the southeastern coast of China.

\section{Qing Government's Administration of Kyakhta Trade}

As early as before the signing of The Treaty of Kyakhta, during the reign of Emperor Kangxi, the Qing Dynasty began its early border trade with Russia through the signing of the Treaty of Nebuchu. At that time, the border trade between Qing Dynasty and Russia was mainly concentrated in Kulun. Kulun's border trade was becoming larger and larger and many businessmen gathered in Kulun for business activities. However, because the Qing government was basically in a state of unregulated border trade in Kulun at that time, there were even many disputes among businessmen, which attracted the attention of the Qing government. According to "The collected institutes and precedents of the Qing dynasty", the Qing government officially set up officials to manage the Kulun border trade in 1720 (the reign of Emperor Kangxi), and implemented the system of licence (zhaopiaozhi du).

${ }^{1}$ The licence was issued by the Qing government to inland businessmen to allow them to go to Mongolia for business. The Qing government stipulated that inland businessmen traveling to Inner Mongolia to engage in trade must obtain a licence stamped with the seal of the emperor as a passport before they could go to Mongolia for business. The number of businessmen, their names, and the location of the trade area would be recorded in detail on the licence. Businessmen traveling to Mongolia were required to carry out business activities in accordance with the date, place and scope of trade specified on the licence, and the licence would be returned to the government after the completion of business activities.

After the signing of The Treaty of Kyakhta, the Qing Dynasty and Russia divided Kyakhta on the Mongolian plateau into two parts. Russia adopted the name of "Kyakhta" on the one side and set up the marketplace to carry out border trade, and on the other hand, the Qing Dynasty set up the marketplace to carry out border trade and people used to call it a "trading city". The Qing dy${ }^{1}$ It should be noted that the the system of licence (zhaopiaozhi du) was not originated in the Qing Dynasty (recorded since the Tang Dynasty already to control people for political, economic and military considerations). The system of licence in Qing Dynasty was an inheritance of the previous dynasty's experience, as well as the the result of the Qing Dynasty's ban on Mongolia. On one hand, in order to prevent the threats of various Mongolian ministries against the Qing Dynasty, a ban policy in Mongolia was implemented by the Qing government, severely dividing and controlling the exchanges between Mongolian ministries. This ban was also extended to prohibit private exchanges between Mongolian ministries and the mainland Han people. On the other hand, the nomadic economic attributes of Mongolian ministries lead to their dependence on the agricultural economy in the Mainland. The complete ban on economic exchanges between the Mongolian ministries and the mainland will affect their livelihood as well as the stability of the Mongolian region. After weighing the pros and cons, the Qing government adopted a more flexible passport system, allowing the mainland Han people to interact with Mongolian ministries under the framework set by the Qing government. 
nasty official has always referred to the two marketplaces as "Kyakhta". When the Qing Dynasty and Russia conducted border trade in Kyakhta, they still followed the licence system that appeared in the Kulun border trade. It required businessmen to hold a licence with the words Kyakhta issued by the central government of the Qing Dynasty before going to Kyakhta for business activities. Apart from the strict restrictions on businessmen imposed by the licence system, the border setting between the two countries in Kyakhta is not strictly enforced. In places where businessmen from both sides did business, they were separated by simple fences. Businessmen from both sides could transit to each other' $s$ countries at will during the day for business activities.

In 1780 (during the reign of Emperor Qianlong), the Qing government revised the original system of licence. It required businessmen to show their licence issued by the central government of the Qing Dynasty when they went to the border control office of Kyakhta, and then another licence was issued to businessmen by the border control office of Kyakhta. Then businessmen were allowed to go to the business offices of the two countries in Kyakhta for business activities only after they got the licence.

When the Qing Dynasty signed The Treaty of Kyakhta with Russia, it was agreed that the border trade between the two countries should not use currency, but trade in goods. In order to avoid raising the price of Russian goods in this barter trade, the Qing government required businessmen to set a unified price for goods sold to Russia. In 1768, Emperor Qianlong asked ministers to draw up charters specifically for Kyakhta trade. One of the provisions stipulated that the goods sold to Russia from Qing Dynasty were divided into eight categories, and the businessmen were divided into eight fields according to the types of goods they sold. A leader was chosen from among the businessmen in each field, and he and the businessmen in his field agreed on the price of the goods they sold. After agreeing on a uniform price, they could not lower the price at will, and even if they raised the price or lowered the price, they had to do it together.

By the 19th century, the Qing Dynasty still used the system of licence, trade in goods and uniform pricing established in the 18th century in the trade of Kyakhta. Besides, the government of the Qing Dynasty also issued secret instructions to officials in charge of the trade in Kyakhta, asking them to pay attention to the changes in the demand for Qing Dynasty goods in Russia while managing border trade, and to avoid the backlog of goods transported from the mainland to Kyakhta, so as to keep the goods of the Qing Dynasty in a best-selling state in Russia. In addition, the government required officials to restrain businessmen from buying Russian goods even when they were in urgent need, so as to avoid Russian businessmen raising their prices (Compilation of National Library, 2003) (Jia, 1966) (Wang, 1957) (Compilation of Gansu Province Ancient Books and Documents Collection Center, 2012).

\section{Businessmen and Goods in Kyakhta Trade}

The active businessmen and the goods they sold in the Kyakhta trade were rec- 
orded in the historical materials of the 18th to 19th centuries. However, the information recorded was rather scattered. According to these scattered information, we could only roughly infer the characteristics of businessmen and goods in border trade at that time.

\subsection{Official Businessmen in Kyakhta Trade}

According to historical records, during the reign of Emperor Qianlong, the Qing government sent Shanxi businessmen to Kyakhta to buy horses and leather and fur. However, in the later historical materials, no record of the official dispatch of businessmen and caravans has been found.

Moreover, the relevant historical materials of the Qianlong period also recorded that from 1760 to 1777 , the Qing government sent caravans of Hui businessmen to Kyakhta to buy Russian goods. These Hui businessmen, who had previously served the Junggar tribe, had rich experience in goods trading with Russia, and some were good at Russian. These team of Hui businessmen usually consisted of 10 to 30 businessmen, led by one or two officials sent by the Qing government (the Qing government did not send officials to supervise the Shanxi businessmen sent), bringing goods worth about 22,000 from Beijing or Zhangjiakou in exchange for Russian goods.

According to historical records, after 1780, the Qing government no longer sent official caravans to trade in Kyakhta. The Japanese scholars analyzed it was because the Qing government did not get much profit from sending official caravans to the border trade.

\subsection{Folk Businessmen in Kyakhta Trade}

The folk businessmen of the Qing Dynasty were very active in the trade of Kyakhta. Due to the advantages of geographical location, Shanxi businessmen were the first to participate in the trade with Russia in Kyakhta and gradually became the largest commercial group in Kyakhta trade. The fixed shops of these businessmen were often located in Zhangjiakou or Guihua City. Historical records showed that businessmen formed caravans to Kyakhta and each caravan consisted of seven businessmen and forty camels (camels were used to transport goods). Some caravans used carriages and ox carts as transport vehicles.

Although the Qing government did not send officials to supervise these private businessmen, it still exercised strict control over them. These businessmen mentioned above must obtain the licence issued by the Qing government before they could go to the market of Kyakhta for trading activities. In addition, the Qing government strictly prohibited these businessmen from marrying and acquiring property in Kyakhta. The purpose was to prevent these businessmen from settling permanently in Kyakhta, establishing increasingly close ties with the Mongol ministries and Russia, and gradually escaping the control of the Qing government. 


\subsection{Major Goods in Kyakhta Trade}

\subsubsection{Russia's Main Goods Exported to the Qing Dynasty}

In the 18th century, the long-term dominant position of goods exported from Russia to the Qing Dynasty was all kinds of leather and fur. The largest number of leather and fur imported from Russia by the Qing Dynasty was mink fur, followed by fox fur. In addition, the leather and fur of silver rat, weasel, beaver, otter and rabbit also occupied a significant position in the imported leather and fur. According to Russian historical records, fur exports in Kyakhta accounted for $85 \%$ of Russia's total exports between 1757 and 1784. However, this proportion gradually decreased after 1784 . Historical records from 1826 showed that in the Kyakhta trade of that year, Russia's exports of furs to the Qing Dynasty accounted for only $47.5 \%$ of its total exports.

The decrease of the amount of fur exported to Qing Dynasty did not mean the decrease of the trade volume between the two sides, which was mainly related to the change of the goods structure of Russian export to Qing Dynasty. While the export of fur decreased, the proportion of non-fur goods increased gradually. By the 19th century, woolen cloth, iron ware, and livestock were the main goods exported from Russia to the Qing Dynasty (Sladkovsk \& Su, 2008).

\subsubsection{Qing's Main Goods Exported to Russia}

\section{1) $\mathrm{Tea}$}

Long before the signing of The Treaty of Kyakhta, China had gradually become a major exporter of tea. However, the main consumers of tea in Russia at that time were Siberian and Black Sea coastal residents. There was no general demand for tea in the domestic market. After the signing of The Treaty of Kyakhta, the Russian government did not include tea in the purchasing plan of imported goods and this situation lasted until the end of the 18th century. According to Russian historical records, important changes took place in the structure of Russian imports from the Qing Dynasty at the end of the 18th century. One of the most important manifestations was the rapid increase in tea imports, the black tea, green tea and tea brick of the Qing Dynasty found a wide market in Russia. This trend may have something to do with the gradual formation of the Russian habit of drinking tea.

By the 19th century, tea was at the heart of the Qing Dynasty's exports to Russia in the Kyakhta trade. Tea has replaced "Chinese cloth" as the value yardstick of goods trade inKyakhta. According to Russian historical data, the share of tea imported through Kyakhta in 1825 accounted for $87.8 \%$ of the total imports of Qing Dynasty goods imported by Russia. In the first half of the 19th century, tea was always the main goods exported to Russia by the Qing Dynasty in the Kyakhta trade. After that, the export volume of tea in Kyakhta gradually decreased, because the opening of Xinjiang border ports diverted part of the share of tea exported to Russia via Kyakhta. Moreover, after 1860, with the opening of Tianjin port, British businessmen began to intervene in the tea export trade of the Qing Dynasty. Because of the lower sea freight, the sea-lane tea trade has 
become a serious challenge to the overland tea trade in Kyakhta (Compilation of Tianjin Archives, 2013).

\section{2) Other goods}

Apart from tea, in the Kyakhta trade, the main goods exported to Russia by the Qing Dynasty included rhubarb, "Chinese cloth" and so on.

Rhubarb was mainly used as traditional Chinese medicine in China but as food and dye in Russia. Russia attached great importance to rhubarb and it implemented state monopoly trade in rhubarb trade and did not allow private trading. After the signing of the Treaty of Kyakhta, rhubarb became one of the important goods exported to Russia by Kyakhta in the Qing Dynasty. Even Russia would specially appointed a giant businessman to purchase rhubarb in Kyakhta. In the Qing Dynasty, Qinghai businessmen mainly traded rhubarb in Kyakhta.

"Chinese cloth" was also popular in Russia. Because of its popularity, it even served as a measure of value in the goods trade of Kyakhta in the 18th century, and its status was not replaced by tea until the 19th century. In the 19th century, with the development of Russian weaving industry, the demand for "Chinese cloth" was greatly reduced, and "Chinese cloth" gradually lost its important position among the goods exported to Russia in the Qing Dynasty.

\section{Conclusion}

First, from the 18th to the 19th century, the Qing government adopted a license system, the barter system and unified pricing system to manage the border trade in Kyakhta. On the one hand, these trade management methods ensured that the trade activities of Mainland businessmen in the Mongolian region were controlled by the Qing government. On the other hand, they ascertained that the currency did not flow out, thereby safeguarding the common interests of Qing merchants.

Second, although the Qing government showed little interest in developing border trade and only strengthened the management of Kyakhta trade out of concern for Mongolia, the development of Kyakhta trade still promoted the development of manufacturing and handicraft industry in China at that time. At the beginning of the Kyakhta trade, the popularity of Chinese cotton textiles, especially "Chinese cloth" in Russia promoted the production of cotton textiles in the Chinese mainland. The demand of international market promoted the production technology and scale of Chinese cotton textiles. The growing market demand for tea in Kyakhta trade has greatly promoted the development of tea production in China. The growing of tea in tea-producing areas was promoted by the commercial firms led by Shanxi businessmen who purchased tea in large quantities from various tea-producing regions in mainland China. Moreover, in order to adapt to the tastes of Russia and other Europeans, these tea-producing areas also produced plenty of new types of tea to the Kyakhta market.

Third, as for the research on China's foreign trade history, the academic ex- 
ploration on trade externalization and internationalization in Inner Mongolia and Outer Mongolia is much weaker than the research on the southeast coast and other parts in the north. This article analyzes the development characteristics of foreign trade in Mongolia during the Qing Dynasty by collecting scattered information and previous research results in historical materials. The current research also enriches the literature on China's foreign trade history.

\section{Fund}

This paper is one of the research results of the western and border region project of the Youth Fund for Humanities and Social Sciences Research of the Ministry of Education of the People's Republic of China in 2018, "Research on the Externalization of Trade in Modern Inner Mongolia under the Opening of Ports and Commerce", Project approval number: 18XJC850001.

\section{Conflicts of Interest}

The author declares no conflicts of interest regarding the publication of this paper.

\section{References}

Compilation of Gansu Province Ancient Books and Documents Collection Center (2012). Literature Series of North China. Beijing: Xueyuan Publishing House.

Compilation of National Library (2003). Compilation of Copies of Frontier Historical Materials in Qing Dynasty. Beijing: Thread-Binding Books Publishing House.

Compilation of Tianjin Archives (2013). Tianjin Customs Archives (1895-1946). Tianjin: Tianjin Ancient Books Publishing House.

Jia, Q. (1966). The Collected Institutes and Precedents of the Qing Dynasty. Modern Chinese Historical Materials. Taipei: Taiwan Wenhai Publishing House.

Sladkovsk, M. Y., \& Su, F. L. (The Soviet Union) (Translation) (2008). History of Trade and Economic Relations between Russian Nationalities and China. Beijing: Social Sciences Academic Press.

Wang, T. Y. (1957). Compilation of the Old Testament at Home and Abroad. Shanghai: Joint Publishing. 